УДК 372.881

DOI: $10.24144 / 2617-3921.2020 .18 .339-347$

\author{
старший викладач кафедри полікультурної освіти та перекладу \\ ДВНЗ «Ужггородський національний університет» \\ orcid.org/0000-0001-9393-7799 \\ м. Ужгород, Україна, +38(066)0993580 \\ allaliashyna@gmail.com
}

\title{
Деякі особливості методики викладання перекладу в полікультурному середовищі
}

Анотація. Актуальність статті зумовлена необхідністю нових підходів до навчання усного перекладу. Характерною ознакою сучасного суспільного розвитку $\epsilon$ глобалізація. Культурна глобалізація сприяе розширенню міжкультурного спілкування. Міжкультурна співпрачя повинна сприяти взаєморозумінню між народами шляхом створення умов для довіри, діалогу та миру. Глобалізаџія знань неможлива без перекладу. Саме переклад дає змогу транслювати знання з однісї культури в іншу. Роль перекладача у цьому прочесі надзвичайно важлива. У статті розглядається використання методу рольової гри як невід'ємної частини сучасних технологій навчання, який забезпечує оволодіння нормами мовної культури, як засіб активізації професійних компетениій майбутніх фахівиів у галузі перекладу. Матеріалом дослідження слугував метод рольової гри у процесі підготовки перекладачів. Методика дослідження полягає в комплексному застосуванні різних методів: теоретичного, емпіричного, статистичного та методу моделювання. На наш погляд, ией метод, який дає змогу студентам перебувати в ситуаиіі міжкультурної взаємодії, максимально наближеної до реальності, є одним $з$ найефективнішим у методиці навчання усному перекладу. Для забезпечення автентичності ситуаиії міжкультурної взаємодії на перший план виходить метод рольової гри. Навчальні рольові ситуації створюють мотивацію для здійснення професійних компетениій усного перекладача. Проведене нами дослідження показало високу ефективність методу рольової гри при навчанні усному перекладу. Результати дослідження дали змогу зробити такі теоретичні узагальнення: рольова гра підвищує мотивацію студентів, розвиває мислення, пам'ять та уяву, дає змогу використовувати мову в різних аспектах, зрозуміти тонкощі комунікації, полегшує входження студента у фахову діяльність перекладача.

Ключові слова: технологія навчання, рольова гра, перекладач, міжкультурна комунікація, перекладаџькі компетенції, екстралінгвістичні фактори. 
Abstract. The article deals with the problem of choosing proper methods in the process of teaching translation technics. The relevance of the article is due to the need for new approaches to teaching interpretation. A characteristic feature of modern social development is globalization. Cultural globalization contributes to the expansion of intercultural communication. Intercultural cooperation should promote mutual understanding between peoples by creating conditions for trust, dialogue and peace. Globalization of knowledge is impossible without translation. It is translation that makes it possible to transfer knowledge from one culture to another. The role of the translator in this process is extremely important. The article presents the role play method as a means of enhancing professional competencies of future specialists in interpreting. The article considers the use of the role play method as an integral part of modern learning technologies, which ensures the mastery of language culture, as a means of enhancing the professional competencies of future professionals in the field of translation. The material of the research was the method of role play in the process of training translators. The research methodology consists in the complex application of different methods: theoretical, empirical, statistical and modelling methods. In our opinion, this method, which allows students to be in a situation of intercultural interaction, as close as possible to reality, is one of the most effective of the interpretation teaching methods. Learning role situations create motivation for the implementation of professional competencies of an interpreter. Our study showed the high effectiveness of the method of role play in teaching interpretation. We came to the conclusion that role play increases students' motivation, develops thinking, memory and imagination, allows to comprehend the intricacies of communication, facilitetes students to come into the scope of translator.

Keywords: teaching technology, role play, interpreter, intercultural communication, translation competencies, extra-linguistic factors.

Вступ. Характерною ознакою сучасного суспільного розвитку є глобалізація. Цей процес відбувається не тільки в політиці, економіці, але й в культурі та освіті. Культурна глобалізація сприяє розширенню міжкультурного спілкування. Міжкультурна співпраця повинна сприяти взаєморозумінню між народами шляхом створення умов для довіри, діалогу та миру. Справедливий обмін та діалог між цивілізаціями, культурами і народами на основі взаємного розуміння та поваги, рівної гідності всіх культур є необхідною умовою для побудови соціальної згуртованості, примирення та миру між народами [13, с. 26].

Оскільки знання іноземних мов не масове явище, перекладачі виступають посередниками між народами в різних сферах життя. Навіть глибоке знання іноземної мови недостатнє для ефективного міжкультурного спілкування. Тому мова повинна вивчатися у тісному зв'язку з культурою народу, мова якого вивчається. Глобалізація знань неможлива без перекладу. Саме переклад дає змогу транслювати знання з однієї культури в іншу. Роль 
перекладача у цьому процесі надзвичайно важлива. Вплив глобалізації спричинив значні мовні та соціальні наслідки в такій сфері, як переклад. Індустрія перекладу стала частиною системи міжнародних зв'язків. Переклад в умовах глобалізації - це надзвичайно складна інтелектуальна діяльність, яка вимагає глибоких знань мови і культури країн, а також крос-культурних відмінностей. Перекладач є надзвичайно важливим та невід'ємним аспектом міжкультурної комунікації.

Розширення міжнародного співробітництва України 3 іншими державами світу робить по-новому важливою роль перекладу як особливого виду міжкультурного спілкування, виду мовного посередництва, мета якого максимально наблизити двомовну комунікацію до одномовної [8, с.71].

Вимоги до підготовки перекладача, його професійних компетенцій, рівня ерудиції неухильно зростають. Це вимагає від викладачів вищої школи сучасних підходів до організації навчального процесу.

Проблема професійної підготовки перекладачів стала предметом наукових пошуків сучасних дослідників. Наприклад, Т. Кучай, Н. Мараховська, О. Павлик, О. Чередниченко, Т. Рудницька розглядають переклад у контексті аналізу проблем перекладознавства та формування особистості перекладача в епоху глобалізації, у контексті методики викладання перекладу. Значний внесок у теорію і методику підготовки перекладачів зробили такі науковці, як: А. Козак (формування перекладацької культури), С. Коломієць (навчання галузевого перекладу), Ю. Колос (формування IT компетентнцій майбутніх перекладачів), О. Шупта (формування готовності до творчої професійної діяльності майбутніх перекладачів) та ін. У дисертації І. Бахова акцентується увага на актуальності формування міжкультурної професійної компетентності перекладача. Т. Ганічева провела експериментальне дослідження методики навчання усного двостороннього перекладу в галузі права.

Підхід до процесу перекладу змінився з лінгвістично-орієнтованого на культурно-орієнтований. Новий підхід до підготовки перекладачів для ефективної професійної діяльності у полікультурній комунікації викликаний потребами суспільства щодо наведення мостів порозуміння у спілкуванні між представниками не тільки різних мов, а й різних культур [9, с.32]. Міжкультурна компетентність дає змогу перекладачеві вийти за межі своєї культури, не втрачаючи своєї культурної ідентичності. Згідно з І.Баховим міжкультурна компетентність як один 3 важливих складників професійної культури перекладача $\epsilon$ інтегративним особистісним утворенням, яке характеризується сукупністю знань, умінь, ціннісних орієнтацій, що зумовлює успішність міжкультурної діяльності 3 вирішення професійних завдань в умовах міжкультурної взаємодії у стилі співробітництва і толерантності [3, c.16]. 
Методологія та методи дослідження. Методика дослідження полягає в комплексному застосуванні різних методів: теоретичного, емпіричного, статистичного та методу моделювання.

Виклад основного матеріалу дослідження. У запропонованій статті розглядається одне $з$ питань, що стосуються особливостей фахової підготовки перекладачів у галузі міжнародних відносин. Наукові підходи до різних напрямів сучасних наукових досліджень у сфері методики викладання теорії та практики перекладу набувають особливого значення у час глобалізації. Слід зазначити, що методичні питання професійного навчання перекладачів досліджували сучасні вітчизняні та зарубіжні науковці, як от: К. Гаращук, Ю. Жлуктечко, І. Зимня, Р. Зорівчак, В. Коптілов, С. Кульчицький, Л. Латишев, А. Паршин, С. Романова, Н. Соболь, І. Халєєва, Л. Черноватий, В. Балабін, І. Гуревич, Л. Пуховська та ін. Але в методиці викладання перекладу є ціла низка ще не вирішених питань. У праці Л.Черноватого «Методика викладання перекладу» розглядаються проблеми викладання перекладу як спеціальності. І. Халєєва розглядає нову стратегію підготовки фахівців у сфері перекладу, покликаних здійснювати не тільки міжмовну, а й міжкультурну комунікацію між народами.

Як зазначає С.В. Баранова, переклад наочно демонструє студентам практичну цінність володіння іноземною мовою і тим самим посилює мотивацію до іiі вивчення. Постійне співставлення іноземної та рідної мов сприяє глибшому пізнанню тієї чи іншої мови [2, с.13].

Переклад відрізняється від інших видів мовленнєвої діяльності не тільки тим, що він поєднує аудіювання і говоріння, але й тим, що він здійснюється в умовах двомовності. Як вважає С.М.Сироваткін, переклад за своєю суттю $\epsilon$ процесом психологічним. Психологічним характером вирізняються три його стадії (розуміння вихідного тексту, його інтерпретація і вибір форми мови перекладу або переформулювання [11]. Тому для вивчення особливостей перекладацької діяльності варто користуватися психолінгвістичними дослідженнями.

Психологічна наука наголошує на необхідних рисах фахівця, який здійснює перекладацьку діяльність, а саме: емпатія, емоційна стійкість, комунікабельність, відповідальність, творчість, постійна праця над удосконаленням своїх навичок, вербальна оригінальність, образна оригінальність, швидкість та гнучкість мислення, полікультурна компетентність. В сучасних психологічних дослідженнях перекладацька діяльність розглядається з точки зору міжкультурної комунікації, так званого діалогу культур. Такий аналіз ми бачимо у працях М.М. Бахтіна, С.Ю. Курганова, У. Ламберта, Н.О. Михальчук, С.О. Мусатова, О.Д. Швейцера та ін . Т.О. Долга розглядає перекладацьку діяльність як реалізацію суб'єкт-суб'єктного крос-культурного усного спілкування та розкриває психологічні передумови вдосконалення усної перекладацької діяльності студентів: готовність до здійснення перекладацької діяльності 


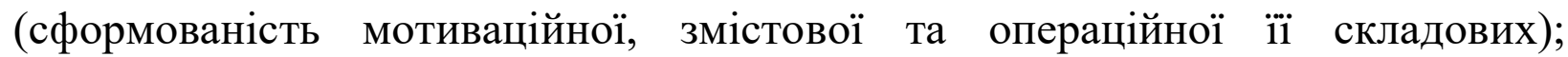
адекватне сприймання та розуміння інформації; готовність до реалізації усіх трьох фаз здійснення перекладацької діяльності: мотиваційно-спонукальної, орієнтаційно-дослідницької та виконавчої; сформованість у студентів груп знань, умінь та навичок, які необхідні для здійснення усної перекладацької діяльності фахівцем; високий рівень розвитку творчого мислення майбутнього перекладача [7, с.17].

Правильний вибір методу і належним чином організована система вправ гарантує опанування студентами практичними навиками. Існують різні види перекладацьких вправ, як от: тренування темпу усного мовлення, тренування переключення на іншу мову, усний переклад 3 аркуша, тренування двостороннього перекладу, збільшення активного запасу частотної лексики. Розроблена система, яка складається з трьох підсистем і включає групи вправ для подолання граматичних, лексичних, жанрово-стилістичних труднощів; для розвитку навичок перекладу реалій, іншомовних слів, назв, вживання перекладацьких трансформацій, для розвитку механізму вибору еквівалентів, навичок переключення з одного коду на інший - диктант-переклад [12, с.152].

3 психологічної точки зору для процесу перекладу характерним $\epsilon$ перемикання мислення людини з однієї бази однієї мови на базу іншої. У працях В.Б.Беляєва, І.О.Зимньої, Л.В.Щерби та ін. проаналізований усний переклад, який характеризується слуховим сприйняттям, складним запам'ятовуванням, перемиканням з однісї мови на іншу (обмежене в часі), усним оформленням.

Сучасні технології навчання іноземним мовам та перекладу дуже різноманітні. Але враховуючи психологічні аспекти перекладу, ми зацікавилися одним з методів, запропонованих М. Авраменком, а саме метод рольової гри, який полягає у штучному створенні ситуації, максимально наближеної до реальної [1]. На наш погляд, цей метод, який дає змогу студентам перебувати в ситуації міжкультурної взаємодії, максимально наближеної до реальності, є одним 3 найефективнішим у методиці навчання усному перекладу. Навчальні рольові ситуації створюють мотивацію для здійснення професійних компетенцій усного перекладача. Згідно 3 дослідженням О.В. Сергеєвої метод рольових та ділових ігор $є$ досить популярним у Великій Британії (62\%). Майбутні перекладачі завдяки цьому методу легко та ефективно долають мовні бар'єри, знайомляться 3 особливостями інших культур, вивчають традиції і звичаї народів, мови яких вивчають [4, с.151].

У перекладознавстві існує термін «комунікативна ситуація». Основна відмінність комунікативної ситуації усного перекладу від мовленнєвої полягає в тому, що мінімум два комуніканти спілкуються різними мовами. У нашому дослідженні ми розглядаємо ситуації за участю перекладача. Ми розглядаємо ситуацію культурної взаємодії. Будучи учасником такої ситуації, перекладач знаходиться в очікуваних або неочікуваних обставинах і вирішує різні 
перекладацькі задачі. На нашу думку, для навчання забезпечити автентичність ситуації міжкультурної взаємодії на перший план виходить метод рольової гри. У рольових навчальних ситуаціях самі студенти виконують ролі іншомовних комуні кантів. У змодельованих ситуаціях майбутній перекладач вчиться оцінювати ступінь культурної узгодженості, а, отже, долати міжкультурні бар'єри. Рольова гра - це метод навчання, який дає змогу студентам взаємодіяти у процесі покладеного на них роллю завдання. Фахового перекладача неможливо уявити без високого рівня загального розвитку, начитаності, широти світогляду. Ці якості формуються у процесі практики, тому доцільно використовувати педагогічні технології, які базуються на ситуаціях, що моделюють практичну діяльність перекладача. Однією з таких технологій і є рольова навчальна гра. Проведення рольових ігор має бути належним чином підготоване і передбачає певний рівень володіння іноземною мовою. Ефективність методу рольової гри забезпечується опрацюванням відповідних лексико-граматичних конструкцій. Рольова гра повинна бути організована так, щоб міжкультурна ситуація мала не тільки професійний, але й освітній контекст, який би сприяв удосконаленню та розвитку перекладацьких компетенцій.

Різні культури мають різні мовні реакції. Оволодіння ними відіграє важливу роль у процесі опанування типом мислення, характерним для певного мовного співтовариства. Пізнаючи культурну картину англомовних країн, студенти порівнювали іiі з рідною. Усвідомлюючи той факт, що в кожному мовному i культурному співтоваристві існує своє уявлення про загальну картину світу, фахівці виконують свої перекладацькі задачі, враховуючи його.

У ході нашого дослідження був проведений експеримент, у якому брали участь 120 студентів спеціалізації «Міжнародні відносини» різних років навчання (3-5 курсів). Експеримент охоплював практичні заняття з теорії та практики перекладу, які проводилися тричі на тиждень по дві академічні години протягом двох років. Усі студенти, залучені до експерименту, мають певні знання лексики, граматики англійської мови та реалій країни, мова якої вивчається. Мета практичного заняття - поглиблювати, поширювати та деталізувати знання, виробляти навички професійної діяльності, розвивати наукове мислення та мовлення, перевіряти знання студентів, мати засіб оперативного зворотнього зв'язку. Практичні заняття грунтуються на попередньо підготовленому методичному матеріалі: тестах, наборі завдань різної складності для різних типів перекладу та їх аналізу, завдання для редагування та реферування текстів, уривки відео- та аудіо текстів для перекладу, завдання для рольових професійних ігор [10].

Т.О.Долга рекомендує в основу рольових ігор покласти такі стратегії перекладацької діяльності майбутніх фахівців, як: стратегію актуалізації культурно специфічного змісту в концептуальній інформаційній системі; інтуїтивну стратегію; стратегію співвіднесення змісту слова або фрази 3 образом свідомості, який існує в носія іноземної мови; стратегію використання 
іконічно мотивованих знаків; стратегію подвійної актуалізації змісту; діяльнісну стратегію; стратегію прогнозування; стратегію перекладацької рефлексії [7, с.13]. Відповідно до цих стратегій ми проводили аналіз перекладацької діяльності студентів.

Рольові ігри вимагають творчого підходу та активної участі як студентів, так i викладача. За формою рольових ігор ми використовували такі: конференція, прес конференція, круглий стіл, перемовини. Ми моделювали реальні події міжнародного рівня і таким чином моделювали реальні перекладацькі задачі. У студентів формується уявлення про правила і норми роботи на міжнародних зустрічах. Важливим етапом $є$ аналіз перекладацької роботи. Ми це проводили з використанням відеозапису, що виявилося дуже ефективним.

Підготовку до рольової гри ми проводили за таким алгоритмом:

читання та переклад фахового тексту;

виконання вправ на опрацювання лексичного та граматичного матеріалу;

аудіювання діалогу;

відтворення діалогу;

складання діалогів з опрацьованою лексикою;

дискусія на задану тему.

Спочатку рольові ігри проводилися на задану тему з прописаними репліками. Такі завдання дають змогу викладачеві чітко визначити питання для обговорення, коло перекладацьких проблем для вирішення, максимально використовувати студентами вивчену лексику. Надалі створювалися ситуації для спонтанного обміну репліками, максимально наближені до природньої комунікації. Ми зосереджувалися не на дослівному перекладі, а на створенні тексту, який би був повноцінною заміною оригінального.

У процесі підготовки до рольових ігор студентам доводиться опрацьовувати додатковий матеріал, що сприяє поповненню словникового запасу. Переглядаючи відео конференції 3 перекладом, таким чином спостерігаючи за процесом перекладу збоку, студенти мають змогу звернути увагу на низку екстралінгвістичних факторів, які обговорюються після перегляду. Такі фактори значно ускладнюють роботу перекладача:

перекладач не дочув сказане;

учасники розмови перебивають один одного;

учасники розмови перебивають один одного і перекладача;

у мові учасників уживається багато вставних слів;

у мові учасників порушена логічна структура.

Тому необхідно звернути увагу на відпрацьовування дій студентів у подібних ситуаціях.

На завершення експерименту ми порівняли ефективність обраного нами методу рольової гри для навчання усного перекладу з методами, основаними на перекладах тексту, і виявили значну перевагу цього методу. 
Висновки 3 дослідження. Проведене нами дослідження показало високу ефективність методу рольової гри при навчанні усному перекладу. Результати дослідження дали змогу зробити такі теоретичні узагальнення: рольова гра підвищує мотивацію студентів, розвиває мислення, пам'ять та уяву, дає змогу використовувати мову в різних аспектах, зрозуміти тонкощі комунікації, полегшує входження студента у фахову діяльність перекладача. Якісний та кількісний аналіз, а також оцінка отриманих експериментальних даних дали нам змогу дійти висновку, що найхарактерніші труднощі усного послідовного перекладу: суб'єктивні, мовні та екстралінгвістичні - швидше долаються у ході застосування методу рольової гри. Використовуючи технологію інтерактивного навчання, ми встановили, що цей метод удосконалює загальну культуру спілкування та соціальної поведінки та допомагає студентам оволодіти навичками усного перекладу. Перспективи подальших досліджень полягають у детальнішому вивченні проблеми підготовки перекладачів, у пошуку ефективних шляхів підвищення перекладацької компетенції студентів.

\section{ЛIТЕРАТУРА}

1. Авраменко М.Л. Выбор практических методов и упражнений при обучении переводу. URL: http//www.natek.freenet.kz/2006/ Avramenko.rtf213.

2. Баранова С.В. Актуальні питання методики викладання перекладу. Вісник Сумського державного ун-ту. Сер. Філологічні науки. 2002. №4 (37). C.12-15.

3. Бахов І.С.Формування міжкультурної фахової компетентності майбутніх перекладачів у вищому навчальному закладі: автореф. дис. ... канд. пед. наук: 13.00.04 / Нац. акад. внутр. справ. Київ, 2011. 22с.

4. Бідюк Н.М. Використання педагогічних технологій у підготовці майбутніх перекладачів в університетах Великої Британії / Н.М.Бідюк, О.В.Сергеєва. Наук. часоп. Наи. пед. ун-ту ім. М.П. Драгоманова. Сер.17. Теорія та практика навчання та виховання: зб. наук. праць. К.: вид-во НПУ ім.. М.П. Драгоманова. 2011. Вип.18. С.9-14.

5. Бондаренко О.М., Коротяєва І.Б. Практичні методи та система вправ для формування перекладацької компетенції у студентів-перекладачів. Наук. записки НДУ ім. Гоголя. Сер. Філологічні науки. 2014. С.173-174.

6. Ганічева Т.В. Експериментальне дослідження ефективності методики навчання майбутніх філологів усного англомовного двостороннього перекладу у галузі прав людини. Вісник ХНУ ім. В.Н. Каразіна. 2007. №782. C.188-191.

7. Долга Т.О. Психологічні умови вдосконалення усної перекладацької діяльності студентів-філологів: автореф. дис. ... канд. пед. наук: 19.00.07 / Нац. акад. пед. наук. Київ, 2011. 22 с. 
8. Латышев Л.К. Перевод: проблемы теории, практики и методики: учебник. М.: Просвещение, 1988. 159 с.

9. Підручна З.Ф. Формування професійно-комунікативної компетентності майбутніх перекладачів у процесі фахової підготовки: автореф. дис. ... канд. пед. наук: 13.00.04 / Терноп. нац. пед. ун-т ім. В.Гнатюка. Тернопіль, 2008. 20 с.

10. Про організацію навчального процесу у вищих навчальних закладах: Положення Міністерства освіти і науки України від 2.06.93. URL: http://minagro.gov.ua/page/4943 (дата звернення: 05.03.2019).

11. Сыроваткин С.Н. Теория перевода в аспекте функциональной лингвосемиотики: учебник. Калининград: Калининградский гос. университет, 1978. $84 \mathrm{c.}$

12. Черноватий Л.М. Методика викладання перекладу як спеціальності: підручник. Вінниця: Нова книга, 2013. 276 с.

13. International Year of Languages. Promotion of International Communication. Published for the Department of General Assembly and Conference Management (DGACM). New York 08-55810. October 2008.1000 pp. 